\title{
Winter Wheat Row Spacing and Alternative Crop Effects on Relay-Intercrop, Double-Crop, and Wheat Yields
}

\author{
Leah Sandler, ${ }^{1}$ Kelly A. Nelson, ${ }^{1}$ and Christopher Dudenhoeffer ${ }^{2}$ \\ ${ }^{1}$ Division of Plant Sciences, University of Missouri, Novelty, MO 63460, USA \\ ${ }^{2}$ Greenley Research Center, University of Missouri, Novelty, MO 63460, USA \\ Correspondence should be addressed to Kelly A. Nelson; nelsonke@missouri.edu
}

Received 28 May 2014; Revised 8 December 2014; Accepted 17 December 2014

Academic Editor: Kent Burkey

Copyright (c) 2015 Leah Sandler et al. This is an open access article distributed under the Creative Commons Attribution License, which permits unrestricted use, distribution, and reproduction in any medium, provided the original work is properly cited.

\begin{abstract}
In Missouri as well as much of the Midwest, the most popular double-cropping system was winter wheat (Triticum aestivum L.) followed by soybean (Glycine max (L.) Merr). These two crops can also be used in an intercrop system, but optimal row spacing was important to increase crop productivity. Research was conducted to evaluate (1) winter wheat inter- and double-crop production systems, using a variety of alternative crops, and (2) the impact of different wheat row spacings on intercrop establishment and yields within the various cropping systems. Field research was conducted during droughts in 2012 and 2013. Spacing of wheat rows impacted wheat yields by $150 \mathrm{~kg} \mathrm{ha}^{-1}$, as well as yields of the alternative crops. Narrower row spacings $\left(150 \mathrm{~kg} \mathrm{ha}^{-1}\right)$ and the doublecrop system $\left(575 \mathrm{~kg} \mathrm{ha}^{-1}\right)$ increased yield due to the lack of interference for resources with wheat in 2013. Land equivalent ratio (LER) values determining productivity of intercrop systems of 19 and $38 \mathrm{~cm}$ row showed an advantage for alternative crops in 2013 , but not 2012. This signified that farmers in Northeast Missouri could potentially boost yield potential for a given field and produce additional forage or green manure yields in a year with less severe drought.
\end{abstract}

\section{Introduction}

Double-cropping is a production system that includes the growth of two separate crops at different times in the same growing season. This typically involves harvesting one species followed immediately by planting another. Compared with mono-cropping systems, double-cropping has used climatic, land, labor, and equipment resources more efficiently and produced more total grain in some situations [1]. Doublecropping increased the amount of time land was used for crop production and increased potential profit [2].

In Missouri as well as much of the Midwest and Southern United States, the most popular double-cropping system was winter wheat (Triticum aestivum L.) followed by soybean (Glycine max (L.) Merr) [3]. Research comparing mono-crop and double-crop wheat systems using a variety of other crops such as soybean and grain sorghum (Sorghum bicolor L.) showed double-crop systems increased grain yield and net returns of the overall system $[1,3,4]$. These increases were attributed to greater resource utilization. In humid areas of South America, research found that double-crop systems reached water productivity (0.85 compared to $\left.0.43 \mathrm{~g} \mathrm{~m}^{-2} \mathrm{~mm}^{-1}\right)$ and radiation productivity $\left(0.22 \mathrm{~g} \mathrm{MJ}^{-1}\right.$ to $0.11 \mathrm{~g} \mathrm{MJ}^{-1}$ ) values that were almost two times greater than the sole crop [5]. Resource use was calculated as the product of the proportion of annual resources captured by crops to produce grain yield. Evaluating productivity of water and light, [6] found that double-cropping dramatically increased the productivity of radiation for both dry matter and yield on an annual basis.

Intercropping is the growth of two crops in the same field where the component crops were not necessarily sown at the same time nor harvested at the same time, but were grown simultaneously for a majority of their growing periods. Within an intercropping system, there was normally one main crop as well as one or more added crops often sown later in the season with the main crop being of primary importance for economic or food production reasons [7]. The most common advantage of intercropping was the production of greater yield on a given piece of land by making more efficient use of available resources. This could have been 
due to different rooting characteristics, canopy structure, height, and nutrient requirements or resource use at different times [7-13]. The point at which complementarity became competition among crops could be manipulated through management practices [9]. Row spacing could be critical in determining success of an intercrop as it impacted the crop's response to limiting factors such as light, soil moisture, and nutrients as well as the availability of resources.

Selecting an optimal row spacing was important to improve crop productivity as plants growing in too wide of a row may not efficiently utilize light, water, and nutrient resources. However, crops grown in too narrow rows may result in severe interrow competition. Row spacing also modified plant architecture, photosynthetic competence of leaves, and dry matter partitioning in several field crops [14]. Successful crop mixtures extended the sharing of available resources over time and space and exploited variation between component crops such as rates of canopy development, final canopy width and height, photosynthetic adaption of canopies to irradiance conditions, and rooting depth [7,9].

Light interception was important in intercrop systems and was affected by the crop architecture and canopy structure. Generally, cereals were taller and shaded the component leguminous crop, which is why row spacing and plant arrangement influenced the success of the systems [8]. A single crop each year used only a small proportion of potentially available resources and calculations for the southeast Pampas area in Argentina which indicated that sole crops of wheat, corn, or soybean captured only $20-36 \%$ of the annual incident photosynthetically active radiation [15].

Optimum row spacing helped optimize tillering and ensured increased wheat yields [14]. Wheat sown under narrow-row spacing $(15 \mathrm{~cm})$ produced greater wheat yields due to a significant increase in productive tillers [14]. Narrowrow spacing increased interrow competition while a wider row spacing $(30 \mathrm{~cm})$ increased the number of grains per spike and 1000-grain weight, but did not compensate for the drastic decrease in productive tillers which resulted in decreased grain yields [14]. Similarly, Zhou et al. [16] found that wheat yields were highest for $14 \mathrm{~cm}$ row spacing with yields ranked $14>7>24.5>49 \mathrm{~cm}$. However, Pandey et al. [17] reported that wheat cultivated in $20 \mathrm{~cm}$ rows produced significantly more effective tillers compared to 15 and $25 \mathrm{~cm}$ rows.

Plant spacing and row direction can also affect total weed suppression. During early growth stages, interference between crop and weed plants was commonly affected by the quality of reflected light [18]. The reflection of far-red photons by the stem of one plant lowered the red to far-red photon ratio of light experienced by the stems of neighboring plants [19]. This modified the light environment in the plant stem tissue, which resulted in increased stem elongation. As plants aged, the crop canopy closed and mutual shading further increased the competition for photosynthetic light [19]. The best results were obtained in an east-west row orientation with $20 \mathrm{~cm}$ rows and two hand-weedings. For that management regime, there was a $44 \%$ increase in crop growth and $21 \%$ increase in crop yield compared to a control [18]. Weed biomass was lower $\left(93 \mathrm{~g} \mathrm{~m}^{-2}\right)$ in narrow row spacing $(18 \mathrm{~cm})$ compared to wide row $(36 \mathrm{~cm})$ weed biomass $\left(107 \mathrm{~g} \mathrm{~m}^{-2}\right)$ [19]. In a wheat frost-seeded legume intercrop system, red clover (Trifolium pretense L.) and alfalfa (Medicago sativa L.) were frost-seeded into winter wheat and triticale, and the legume intercrop did not affect grain yield, but did reduce weed density and dry matter up to 40 days after harvest [20]. Champion et al. [21] reported that manipulation of the crop for weed suppression by reducing row width was less successful than increasing plant density in wheat only fields. The authors reported that narrow rows did not enhance shading and suppression of weed biomass; however, the research included wheat only and no intercrops.

Wheat rows in relay-intercropping, the system of intercropping where the intercrop is sowed at a later date than the main crop, are often wider than conventionally planted wheat in order to allow light for the subsequent intercrop. When intercropping clover into wheat, Thorsted et al. [22] found that interspecific competition during vegetative growth was reduced by increasing width of the rototilled strips from 7 to $14 \mathrm{~cm}$, which resulted in greater grain yields and increased grain $\mathrm{N}$ uptake. However, when using wider rows without an intercrop, wider rows did not necessarily benefit yields. Over two years, four different wheat planting patterns were employed including conventional seeding [23]. There were no significant differences among treatments for total above ground dry matter, number of grains per area, grain weight, or grain yield. These findings indicated that there were no negative effects of wide-row planting on wheat yields [23]. However, other research showed that row spacing affected yields; narrow rows yielded more grain compared to wide rows. This suggested that closeness of planting enabled more efficient utilization of resources $[21,24]$.

The most common intercropping system is wheat and a legume such as soybean or red clover, as the nitrogen fixing properties of legumes work well with wheat and a subsequent rotational crop $[7,8,25]$. Research in Wisconsin demonstrated that red clover ( $4200 \mathrm{~kg} \mathrm{ha}^{-1}$ aboveground biomass) was the most productive and reliable legume choice as a green manure crop when it was interseeded into winter wheat in early spring compared to hairy vetch $\left(3385 \mathrm{~kg} \mathrm{ha}^{-1}\right)$ and crimson clover (2050 $\mathrm{kg} \mathrm{ha}^{-1}$ ) [26]. In Michigan, red clover produced significantly more above and belowground biomass (0.97-2.14 $\mathrm{kg} \mathrm{ha}^{-1}$ ) than fallow. Corn $\mathrm{N}$ biomass $\left(109.1-148.1 \mathrm{~kg} \mathrm{ha}^{-1}\right)$ and grain yield $\left(5800-7200 \mathrm{~kg} \mathrm{ha}^{-1}\right)$ were increased by including red clover when compared to fallow [26]. Nitrogen credit from red clover $\left(30-48 \mathrm{~kg} \mathrm{~N} \mathrm{ha}^{-1}\right)$ was similar across management type with the first year of introduction to the conventional system providing an apparent $55 \mathrm{~kg} \mathrm{Nha}^{-1}$ [27]. Relay-cropping increased the average return to $\mathrm{N}$ investments across the $\mathrm{N}$ fertility gradient when estimating $\mathrm{N}$ and forage values of red clover biomass (265-1380 $\mathrm{kg} \mathrm{ha}^{-1}$ ) compared to wheat [28].

Nitrogen application at maximum economic rate (MERN) for wheat decreased economic benefits as well as possible system benefits of red clover. Red clover contribution to the total intercrop yield decreased with $\mathrm{N}$ applications greater than $40 \mathrm{~kg} \mathrm{Nha}^{-1}$; thus the authors argue that reduction of $\mathrm{N}$ rates can maximize economic returns for both wheat and 
red clover and increase profits for both species [28]. Results of a winter annual legume experiment showed that hairy vetch cultivars, especially cv. Hungvillosa, exhibited the best frost resistance compared to yellow sweet clover (Melilotus officinalis (L.) Pall.). At the lowest temperature $\left(-9^{\circ} \mathrm{C}\right)$, hairy vetch Hungvillosa had the largest relative biomass ( $75 \%$ of the control of $0^{\circ} \mathrm{C}$ ) [29].

The objectives of this research were to evaluate (1) winter wheat inter- and double-crop production systems, using a variety of alternative crops, and (2) the impact of different wheat row spacings on intercrop establishment and yields within the various cropping systems. Wheat yields, both biomass and grain yields of alternative crops, and light interception data were taken to establish the results for this research. Working in various cropping systems that could potentially maximize resource efficiency would provide farmers in Northeast Missouri opportunities for increased incomes and maximum use of their inputs. This research seeks to provide information on alternative agriculture practices useful to the farmers in the area.

\section{Materials and Methods}

A field trial was initiated in the fall of 2011 and continued through 2013 at the University of Missouri Greenley Research Center near Novelty, Missouri $\left(40^{\circ} 1^{\prime} 17^{\prime \prime} \mathrm{N} 92^{\circ} 11^{\prime} 24.9^{\prime \prime} \mathrm{W}\right)$. Soft red winter wheat, "MFA 2525," was planted in a split-plot design. The main plot was row spacing and cropping system, and subplot was alternative crop species. Four replications were planted in plots that were 3 by $9 \mathrm{~m}$. On 3 October, 2011, wheat was no-till drill seeded at $112 \mathrm{~kg} \mathrm{ha}^{-1}$ in $19 \mathrm{~cm}$ rows using a Great Plains no-till drill (Great Plains Ag., Salina, KS). In plots that would contain wheat in $38 \mathrm{~cm}$ rows but had been planted in $19 \mathrm{~cm}$ rows, every other row was sprayed out using a hand held sprayer containing glyphosate at $1.06 \mathrm{~kg}$ a.i. $\mathrm{ha}^{-1}$ and nonionic surfactants at $0.25 \% \mathrm{vol} . / \mathrm{vol}$. The soil was a Kilwinning silt loam (fine, montmorillonitic, mesic Vertic Ochraqualfs). Wheat planted in October 2011 over-wintered and then was relay-intercropped (4 April) and doublecropped (16 June) in the spring of 2012 and harvested (15 June) in the summer of 2012. The second year of wheat was no-till drill seeded at $112 \mathrm{~kg} \mathrm{ha}^{-1}$ in $19 \mathrm{~cm}$ and $38 \mathrm{~cm}$ rows using a Great Plains no-till drill (Great Plains Ag., Salina, KS) on 11 October, 2012. The soil was a Putnam silt loam (fine, montmorillonitic, mesic Vertic Albaqualfs). Wheat over-wintered and was relay-intercropped (29 April) and double-cropped (3 July) in the spring of 2013 and harvested on 3 July, 2013.

Diammonium phosphate and potassium chloride were broadcast at $35 \mathrm{~kg} \mathrm{Nha}^{-1}, \quad 89 \mathrm{~kg} \mathrm{P}_{2} \mathrm{O}_{5} \mathrm{ha}^{-1}$, and $134 \mathrm{~kg} \mathrm{~K}_{2} \mathrm{O} \mathrm{ha}^{-1}$ on 3 October, 2012. Ammonium nitrate was broadcast spread on all plots at an amount of $111 \mathrm{~kg} \mathrm{Nha}^{-1}$ on 27 March, 2012, and 22 March, 2013, using a hand held fertilizer spreader. On 4 April, 2012, and 2 February, 2013, cowpea (Vigna unguiculata L.) at $56 \mathrm{kgha}^{-1}$, soybean at 440,000 seeds ha ${ }^{-1}$, pea (Pisum sativum L.) at $34 \mathrm{~kg} \mathrm{ha}^{-1}$, hairy vetch (Vicia villosa L.) at $39 \mathrm{~kg} \mathrm{ha}^{-1}$, red clover (Trifolium pretense L.) at $11 \mathrm{~kg} \mathrm{ha}^{-1}$, grain amaranth (Amaranthus hypochondriacus L.) at $11 \mathrm{~kg} \mathrm{ha}^{-1}$, grain sorghum (Sorghum vulgare L.) at $11 \mathrm{~kg} \mathrm{ha}^{-1}$, and pearl millet (Pennisetum glaucum L.) at $17 \mathrm{~kg} \mathrm{ha}^{-1}$ were broadcast seeded into the standing winter wheat. The alternative crops were chosen for a variety of reasons. Pea, cowpea, hairy vetch, and red clover are legume species and could add nitrogen to the soil [7]. Other crops including grain sorghum and grain amaranth have drought tolerance and could be harvested for grain to create additional income as there are potential markets for these crops in Missouri [30].

On 4 April, 2012, and 29 April, 2013, the same eight alternative crops were no-till seeded in $38 \mathrm{~cm}$ rows using a split-row planter (John Deere 7200, Moline, IL) into standing wheat with 19 and $38 \mathrm{~cm}$ rows. Finally, following wheat harvest all subplot crops were no-till, double-crop seeded using a split-row planter (John Deere 7200, Moline, IL) on 16 June, 2012, and 3 July, 2013. Emergence of the alternative crops and stand counts were evaluated on 17 May, 2012, and 5 June, 2013. Heights were recorded on 9 July, 2013. There was no height data recorded in 2012 for alternative crops due to the lack of plant growth from dry conditions. Following the double-crop planting, emergence of the double-cropped alternative crops was recorded on 11 July, 2012, and 11 July, 2013.

Leaf area index (LAI) and light interception (LI) were recorded on 12 June, 2012, and 29 May, 2013, at wheat flag leaf. Data were recorded using a SunScan canopy analysis system (Delta-T, Burwell, Cambridge, UK). Light interception was calculated by measuring both incident and transmitted light through the canopy simultaneously. Intercepted light is the amount of the incident that was not transmitted. Wheat was harvested on 15 June, 2012, and 3 July, 2013, using a $1.5 \mathrm{~m}$ head on a Wintersteiger plot combine (Wintersteiger Delta, 4910 Ried, Austria, Dimmelstrasse 9) and yields were determined per plot. Alternative crops were hand weeded three times throughout the growing season following the harvest of the wheat. Alternative crops were hand harvested from a 0.3 by $0.75 \mathrm{~m}$ quadrat on 9 October 2012 and 2013. Yields were separated into grain and total plant dry matter. Land equivalent ratio (LER) values were calculated using wheat and alternative crop biomass data and the calculation LER $=$ mixed yield $1 /$ pure yield $^{1}+$ mixed yield ${ }^{2} /$ pure yield $^{2}$ [31]. The resulting value indicated the amount of land needed to grow both crops together compared with the amount of land needed to grow a mono-crop of each crop.

Data were subjected to ANOVA [32] and means separated using Fisher's Protected LSD $(P=0.1)$. LAI and LI data were analyzed comparing 19 and $38 \mathrm{~cm}$ row spacing. Wheat yields were combined over site-year in the absence of significant interactions, adjusted to $130 \mathrm{~g} \mathrm{~kg}^{-1}$ grain moisture prior to analysis, and evaluated across row spacing within alternative crops. Emergence, grain, and biomass yields of alternative crops were presented separately across row spacing and site years. LER values were presented separately for years due to an interaction and were evaluated for each alternative crop. Years were presented separately due to significant difference between years especially when yields were significantly impacted by drought in 2012 and compared among cropping systems. 


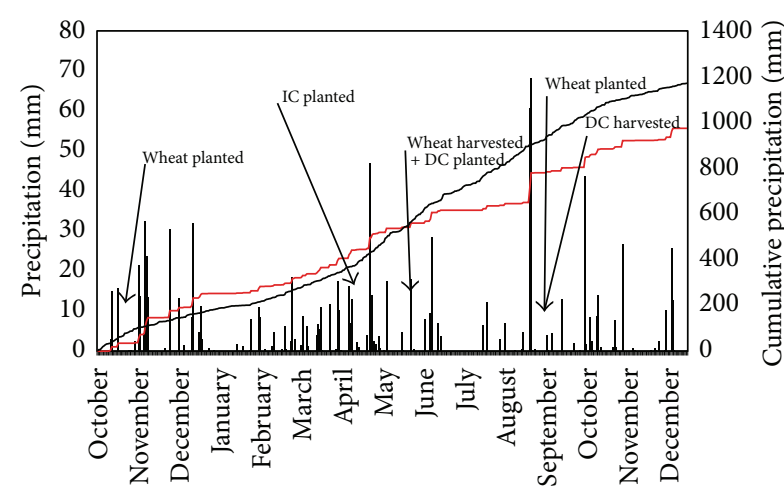

(a)

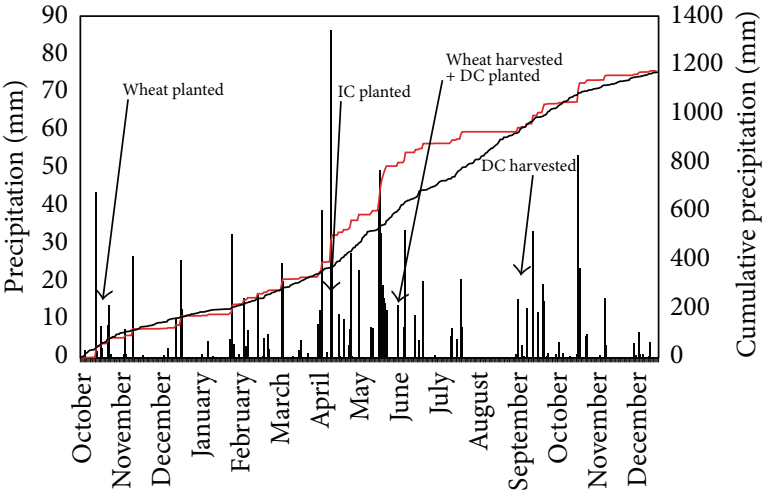

(b)

FiguRE 1: Daily (bar) and cumulative precipitation data for individual years (red line) and 10-year average (black line) for experiment from 2011 to 2012 (a) and 2012 to 2013 (b). Double-crop (DC), relay-intercrop (IC) planting, and harvest dates for wheat and alternative crops were labeled with arrows.

\section{Results and Discussion}

3.1. Environmental Conditions. Annual precipitation for 20112012 was below average and was average for 2012-2013 compared to precipitation data from the last 10 years (Figure 1). During the wheat growing season in 2011-2012 from planting in October through winter total rainfall was $252 \mathrm{~mm}$ (Figure 1(a)). Total precipitation for 2012 was $722 \mathrm{~mm}$; however, there was only $215 \mathrm{~mm}$ of rainfall from May through August, $60 \mathrm{~mm}$ of which occurred on the last day of August. Total precipitation in 2012 was $262 \mathrm{~mm}$ below the 10 -year average for the alternative crops (Figure 1(a)). In 2013, total precipitation was $1003 \mathrm{~mm}$ and again from June through August there was only $140 \mathrm{~mm}$ of rainfall with no rain in August for the alternative crops (Figure 1(b)).

During the summer of 2012, temperatures were abnormally high with an average temperature of $23.7^{\circ} \mathrm{C}$ from May through August and $30.7^{\circ} \mathrm{C}$ was the average high temperature (data not presented). In comparison, 2013 was a relatively cool summer with an average temperature through the summer of $21.2^{\circ} \mathrm{C}$ and an average high temperature of $27.3^{\circ} \mathrm{C}$. Due to below average rainfall as well high average temperatures in 2012, research completed in the growing years of 2011-2012 and 2012-2013 was conducted under dry summer conditions and extreme drought conditions for 2011-2012.

3.2. Light Interception. Light interception was 3\% greater in $19 \mathrm{~cm}$ wide wheat rows than $38 \mathrm{~cm}$ rows in 2011-2012 and similar in 2012-2013 (Table 1). With narrower row spacing, there were probably more wheat plants in the field allowing for greater interception of light. For the 2011-2012 growing season, $19 \mathrm{~cm}$ wide rows also had a greater leaf area index compared with $38 \mathrm{~cm}$ rows. Leaf area index was not different in 2013.

Research has shown that light interception was important in intercrop systems and was affected by the crop architecture and canopy structure $[8,15,19]$. Similarly, Borger et al. [19] found that light interception by crops increased in narrow row spacing by $63 \%$ to $70 \%$ compared to wide rows, while Champion et al. [21] reported that light interception
TABLE 1: Light interception (LI) and leaf area index (LAI) of wheat planted in 19 and $38 \mathrm{~cm}$ wide rows.

\begin{tabular}{lccccc}
\hline \multirow{2}{*}{ Wheat row spacing } & \multicolumn{2}{c}{2012} & & 2013 \\
& LI & LAI & LI & LAI \\
\hline & & & $\%$ & & \\
$19 \mathrm{~cm}$ row & 77 & 2.7 & 89 & 3.6 \\
$38 \mathrm{~cm}$ row & 74 & 2.4 & 85 & 4.0 \\
LSD $(P=0.1)$ & 2 & 0.2 & NS & NS \\
\hline
\end{tabular}

TABLE 2: Wheat yield response averaged across years to relayintercrops planted into 19 and $38 \mathrm{~cm}$ row spacings and following $19 \mathrm{~cm}$ wheat with no mechanical damage that was subsequently double-crop seeded in 2012 and 2013.

\begin{tabular}{|c|c|c|c|}
\hline \multirow{3}{*}{ Crop } & \multicolumn{3}{|c|}{ Cropping system } \\
\hline & \multicolumn{2}{|c|}{ Relay-intercrop } & \multirow{2}{*}{$\begin{array}{c}\text { Double-crop } \\
19 \mathrm{~cm} \\
\end{array}$} \\
\hline & $19 \mathrm{~cm}$ & $38 \mathrm{~cm}$ & \\
\hline & \multicolumn{3}{|c|}{$\mathrm{kg} \mathrm{ha}^{-1}$} \\
\hline Cowpea & 4425 & 3775 & 4715 \\
\hline Pearl millet & 4120 & 4070 & 4665 \\
\hline Sorghum & 4340 & 4195 & 4625 \\
\hline Amaranth & 4105 & 4035 & 4375 \\
\hline Soybean & 4105 & 3925 & 4640 \\
\hline Red clover & 4055 & 4105 & 4660 \\
\hline Hairy vetch & 3935 & 3960 & 4675 \\
\hline Pea & 4150 & 3835 & 4725 \\
\hline $\operatorname{LSD}(P=0.1)$ & \multicolumn{3}{|c|}{435} \\
\hline
\end{tabular}

measurements taken throughout the growth cycle at $10 \mathrm{~cm}$ above ground level varied for different row spacings.

3.3. Wheat Yields. There were no year interactions for wheat yields across both years (2011-2012 and 2013-2013), but the main effect of row spacing affected yield $(P=0.06)$ (Table 2$)$. Wheat yields were $100 \mathrm{~kg} \mathrm{ha}^{-1}$ to $980 \mathrm{~kg} \mathrm{ha}^{-1}$ above average wheat yields for Missouri [33]. Wheat yields were 4375 to 
TABLE 3: Alternative crop emergence in intercrop and double-crop systems on 17 May, 2012, and 5 June, 2013.

\begin{tabular}{|c|c|c|c|c|c|c|c|c|c|c|}
\hline \multirow{3}{*}{ Crop } & \multicolumn{5}{|c|}{2012} & \multicolumn{5}{|c|}{2013} \\
\hline & \multicolumn{3}{|c|}{ Relay-intercrop } & \multicolumn{2}{|c|}{ Double-crop } & \multicolumn{3}{|c|}{ Relay-intercrop } & \multicolumn{2}{|c|}{ Double-crop } \\
\hline & $19 \mathrm{~cm}$ & $38 \mathrm{~cm}$ & No wheat & $19 \mathrm{~cm}$ & $\begin{array}{c}\text { LSD } \\
(P=0.1)\end{array}$ & $19 \mathrm{~cm}$ & $38 \mathrm{~cm}$ & No wheat & $19 \mathrm{~cm}$ & $\begin{array}{c}\text { LSD } \\
(P=0.1)\end{array}$ \\
\hline & \multicolumn{10}{|c|}{1000 plants ha ${ }^{-1}$} \\
\hline Cowpea & 0 & 0 & 0 & 1429 & 299 & 267 & 0 & 0 & 1725 & 67 \\
\hline Pearl millet & 27 & 0 & 0 & 1456 & 459 & 0 & 0 & 0 & 458 & 88 \\
\hline Sorghum & 0 & 0 & 0 & 3181 & 1080 & 81 & 54 & 647 & 1051 & 333 \\
\hline Amaranth & 0 & 0 & 0 & 9167 & 406 & 0 & 0 & 0 & 512 & 358 \\
\hline Soybean & 81 & 108 & 1132 & 1833 & 297 & 1402 & 1510 & 2076 & 1375 & 524 \\
\hline Red clover & 566 & 1456 & 27 & 593 & 1190 & 3396 & 4259 & 9111 & 4178 & 2290 \\
\hline Hairy vetch & 350 & 997 & 1402 & 2156 & 604 & 3909 & 4259 & 10432 & 2615 & 1670 \\
\hline Pea & 674 & 593 & 1563 & 917 & 242 & 122 & 1267 & 1856 & 943 & 490 \\
\hline
\end{tabular}

$4725 \mathrm{~kg} \mathrm{ha}^{-1}$ in 2012 and 2013 for the double-crop system planted in $19 \mathrm{~cm}$ rows and were greater when compared with relay-intercropping at either row spacing for pearl millet, soybean, red clover, hairy vetch, and pea. Wheat yields for double-cropped soybeans were $535 \mathrm{~kg} \mathrm{ha}^{-1}$ greater than wheat that was relay-intercropped in $19 \mathrm{~cm}$ rows and $715 \mathrm{~kg} \mathrm{ha}^{-1}$ greater than wheat that was relay-intercropped in $38 \mathrm{~cm}$ rows. Double-cropped red clover wheat yields were 555 and $605 \mathrm{~kg} \mathrm{ha}^{-1}$ greater compared to relay-intercropping at $38 \mathrm{~cm}$ and $19 \mathrm{~cm}$, respectively. Similarly, when pea was used as a double-crop wheat yields were greater than the $38 \mathrm{~cm}$ row $\left(715 \mathrm{~kg} \mathrm{ha}^{-1}\right)$ and the $19 \mathrm{~cm}$ intercrop system $\left(740 \mathrm{~kg} \mathrm{ha}^{-1}\right)$. Finally, intercropping hairy vetch decreased yields $575 \mathrm{~kg} \mathrm{ha}^{-1}$ in $19 \mathrm{~cm}$ wheat and $890 \mathrm{~kg} \mathrm{ha}^{-1}$ in $38 \mathrm{~cm}$ wheat compared to double-crop hairy vetch. Relayintercropping cowpea into $38 \mathrm{~cm}$ wheat reduced yields compared to $19 \mathrm{~cm}$ relay-intercrop and double-crop systems 655 and $940 \mathrm{~kg} \mathrm{ha}^{-1}$, respectively (Table 2). There were no differences in wheat yields for grain sorghum or grain amaranth. Double-cropping may have resulted in greater wheat yields due to physical damage from intercropping. Ngalla and Eckert [34] reported a 4\% reduction to wheat due to physical damage to wheat. Double-cropping may have also produced greater wheat yields due to the lack of competition for resources from intercrops $[9,22]$. For soybean, $38 \mathrm{~cm}$ row spacing decreased wheat yields $180 \mathrm{~kg} \mathrm{ha}^{-1}$ compared to $19 \mathrm{~cm}$ rows in either cropping system. This may have been due to competiveness of soybean preventing tillering of wheat that was associated with wider row spacings [17]. Hairy vetch had greater wheat yields in double-cropped systems $\left(4680 \mathrm{~kg} \mathrm{ha}^{-1}\right)$ than either row spacing in the intercrop system $\left(4330 \mathrm{~kg} \mathrm{ha}^{-1}\right.$ for $19 \mathrm{~cm}$ rows and $4150 \mathrm{~kg} \mathrm{ha}^{-1}$ for $38 \mathrm{~cm}$ rows) which was probably due to crop interference.

Research has shown that row spacing can help optimize wheat yields; however, results have differed depending on the selection of narrow or wide row spacing $[14,17,21]$. Wheat sown under narrow row spacing $(15 \mathrm{~cm})$ produced greater wheat yields due to a significant increase in productive tillers [14]. Wider row spacing $(30 \mathrm{~cm})$ increased the number of grains per spike and 1000-grain weight, but could not compensate for the drastic decrease in productive tillers which decreased grain yields [14]. Similarly, Zhou et al. [16] found that wheat yields were greatest for $14 \mathrm{~cm}$ spacing with yields ranked $14>7>24.5>49 \mathrm{~cm}$ row spacing. However, Pandey et al. [17] reported that wheat cultivated at $20 \mathrm{~cm}$ row spacing produced significantly more effective tillers as compared to $15 \mathrm{~cm}$ row spacings. Thorsted et al. [22] found that interspecific competition during vegetative growth was reduced by increasing width of the rototilled strips from 7 to $14 \mathrm{~cm}$, and research completed by [23] indicated that there were no negative effects of wide-row planting on wheat yields. Conversely, narrow rows yielded more grain than wide rows, suggesting that closeness of planting enabled more efficient utilization of resources [21, 24]. Finally, wheat yields may have been affected by row orientation due to impacts on light interception and photosynthetic efficiency $[17,19]$. The effect of row orientation varied with latitude and seasonal tilt of the earth [19]. For example, wheat crops planted east-west in Western Australia had 24\% greater yields than those oriented north-south and 51\% lower weed biomass [19].

3.4. Alternative Crop Yields. Due to the severe drought in 2012, alternative crops in the intercrop system died due to plant interference. While the intercrops emerged (Table 3) prior to wheat harvest on 15 June, all of the intercrops eventually died. There was a severe drought during the summer of 2012 and the intercrop system was burdened by too much competition for water with wheat $[9,15]$. The intercrops died after emergence probably due to lack of water and extreme heat, which was exacerbated by interference with wheat. The double-crop planting produced biomass yields ranging from $145 \mathrm{~kg} \mathrm{ha}^{-1}$ for red clover to $20,295 \mathrm{~kg} \mathrm{ha}^{-1}$ for sorghum (Table 4). With a later planting date, crops received water at important establishment and maturation points that was not available to intercrops earlier in the season. In addition, temperatures started to decrease at the end of the summer, meaning that growth occurred during slightly cooler temperatures (an average temperature of $22.4^{\circ} \mathrm{C}$ from planting to harvest). Finally, the alternative crops planted in the double-crop system did not have to compete with wheat for water and other resources. 
TABLE 4: Dry biomass yields of alternative crops for 2012 and 2013.

\begin{tabular}{|c|c|c|c|c|c|c|c|c|c|c|}
\hline \multirow{3}{*}{ Crop } & \multicolumn{5}{|c|}{2012} & \multicolumn{5}{|c|}{2013} \\
\hline & \multicolumn{3}{|c|}{ Relay-intercrop } & \multicolumn{2}{|c|}{ Double-crop } & \multicolumn{3}{|c|}{ Relay-intercrop } & \multicolumn{2}{|c|}{ Double-crop } \\
\hline & $19 \mathrm{~cm}$ & $38 \mathrm{~cm}$ & No wheat & $19 \mathrm{~cm}$ & $\begin{array}{c}\text { LSD } \\
(P=0.1)\end{array}$ & $19 \mathrm{~cm}$ & $38 \mathrm{~cm}$ & No wheat & $19 \mathrm{~cm}$ & $\begin{array}{c}\text { LSD } \\
(P=0.1)\end{array}$ \\
\hline & \multicolumn{10}{|c|}{$\mathrm{kg} \mathrm{ha}^{-1}$} \\
\hline Cowpea & 0 & 0 & 0 & 2370 & 740 & 770 & 1065 & 440 & 2715 & 1190 \\
\hline Pearl millet & 0 & 0 & 0 & 3310 & 345 & 0 & 805 & 0 & 1315 & 735 \\
\hline Sorghum & 0 & 0 & 0 & 20295 & 19835 & 3470 & 2930 & 17155 & 5395 & 2755 \\
\hline Amaranth & 0 & 0 & 0 & 1590 & 470 & 40 & 265 & 0 & 930 & 335 \\
\hline Soybean & 0 & 0 & 0 & 3250 & 470 & 715 & 820 & 2670 & 2520 & 1660 \\
\hline Red clover & 0 & 0 & 0 & 145 & 125 & 375 & 930 & 1120 & 250 & 400 \\
\hline Hairy vetch & 0 & 0 & 0 & 1110 & 285 & 1790 & 1165 & 1850 & 770 & 690 \\
\hline Pea & 0 & 0 & 0 & 565 & 225 & 35 & 465 & 0 & 695 & 640 \\
\hline
\end{tabular}

TABLE 5: Alternative crop grain yields for wheat row spacing in 2012 and 2013.

\begin{tabular}{|c|c|c|c|c|c|c|c|c|c|c|}
\hline \multirow{3}{*}{ Crop } & \multicolumn{5}{|c|}{2012} & \multicolumn{5}{|c|}{2013} \\
\hline & \multicolumn{3}{|c|}{ Relay-intercrop } & \multicolumn{2}{|c|}{ Double-crop } & \multicolumn{3}{|c|}{ Relay-intercrop } & \multicolumn{2}{|c|}{ Double-crop } \\
\hline & $19 \mathrm{~cm}$ & $38 \mathrm{~cm}$ & No wheat & $19 \mathrm{~cm}$ & $\begin{array}{c}\text { LSD } \\
(P=0.1)\end{array}$ & $19 \mathrm{~cm}$ & $38 \mathrm{~cm}$ & No wheat & $19 \mathrm{~cm}$ & $\begin{array}{c}\text { LSD } \\
(P=0.1)\end{array}$ \\
\hline & \multicolumn{10}{|c|}{$\mathrm{kg} \mathrm{ha}^{-1}$} \\
\hline Cowpea & 0 & 0 & 0 & 0 & 0 & 0 & 39 & 16 & 4 & 52 \\
\hline Pearl millet & 0 & 0 & 0 & 125 & 45 & 0 & 82 & 0 & 257 & 106 \\
\hline Sorghum & 0 & 0 & 0 & 470 & 235 & 450 & 675 & 2059 & 337 & 698 \\
\hline Amaranth & 0 & 0 & 0 & 410 & 275 & 22 & 50 & 0 & 462 & 70 \\
\hline Soybean & 0 & 0 & 0 & 560 & 365 & 32 & 163 & 859 & 172 & 505 \\
\hline Red clover & 0 & 0 & 0 & 0 & 0 & 0 & 0 & 18 & 0 & 23 \\
\hline Hairy vetch & 0 & 0 & 0 & 0 & 0 & 0 & 0 & 0 & 0 & 0 \\
\hline Pea & 0 & 0 & 0 & 0 & 0 & 0 & 0 & 0 & 36 & 47 \\
\hline
\end{tabular}

Alternative crops yielded greater in 2013 for relayintercrops compared to 2012 with the exception of pearl millet, amaranth, and pea in some spacings. In 2012, there was no yield for intercrops, but in 2013 total biomass reached $17,155 \mathrm{~kg} \mathrm{ha}^{-1}$ for sorghum. Early rainfalls in May and June and cooler summer temperatures allowed for greater intercrop growth before a "flash drought" occurred late in the summer. There were trends that occurred across alternative crops. With the exception of hairy vetch, alternative crops generally yielded greater either in the double-crop system (cowpea, amaranth, and pea) or in the no wheat (grain sorghum and clover) or $38 \mathrm{~cm}$ intercrop system (pearl millet) (Table 4). This most likely occurred because of reduced competition for resources due to either no wheat being present or greater distance between the wheat rows for the alternative crop.

Hairy vetch was the exception with greater biomass yields of $1020 \mathrm{~kg} \mathrm{ha}^{-1}$ for $19 \mathrm{~cm}$ row spacing intercrop and $1080 \mathrm{~kg} \mathrm{ha}^{-1}$ for no wheat compared to $19 \mathrm{~cm}$ double-crops. As a vining plant, hairy vetch probably benefitted in the $19 \mathrm{~cm}$ rows from having wheat stalks closer which provided it with physical support, since hairy vetch is often a frost seeded species [35] and can withstand colder temperatures. However, double-crop planting on 9 July may have caused average temperatures to be too high for good growth of hairy vetch. Visual observations noted that hairy vetch performed very well in Northeast Missouri as an intercrop, often forming ground cover and good biomass production that suppressed weeds such as common waterhemp (Amaranthus rudis Saur.) (visual observation).

There were only four alternative crops that produced grain yield in the double-crop system in 2012 including pearl millet $\left(125 \mathrm{~kg} \mathrm{ha}^{-1}\right)$, grain sorghum $\left(470 \mathrm{~kg} \mathrm{ha}^{-1}\right)$, amaranth $\left(410 \mathrm{~kg} \mathrm{ha}^{-1}\right)$, and soybean $\left(560 \mathrm{~kg} \mathrm{ha}^{-1}\right)$ (Table 5). Cropping system affected alternative crop grain yields in 2013 (Table 5). For pearl millet and amaranth, grain yields were 175 to $412 \mathrm{~kg} \mathrm{ha}^{-1}$ greater in the double-crop system compared to either row spacing in the intercrop system. Similarly, grain yields were greatest for sorghum and soybean in the monocrop system with no wheat. In both the mono-crop, no wheat system and the double-crop system the alternative crop did not have to compete with wheat for resources.

3.5. Land Equivalent Ratio. A LER shows the efficiency of intercropping for using the environmental resources compared with mono-cropping and compares yields obtained by 
TABLE 6: Land equivalent ratios (LER) for intercropping of wheat and all alternative crops for 19 and $38 \mathrm{~cm}$ row spacing.

\begin{tabular}{|c|c|c|c|c|c|c|}
\hline \multirow{2}{*}{ Crop } & \multicolumn{3}{|c|}{2012} & \multicolumn{3}{|c|}{2013} \\
\hline & $19 \mathrm{~cm}$ & $38 \mathrm{~cm}$ & $\operatorname{LSD}(P=0.1)$ & $19 \mathrm{~cm}$ & $38 \mathrm{~cm}$ & $\operatorname{LSD}(P=0.1)$ \\
\hline Cowpea & 0.94 & 0.74 & 0.38 & 1.34 & 1.21 & 0.71 \\
\hline Pearl millet & 0.8 & 0.87 & 0.41 & 0.97 & 1.40 & 0.77 \\
\hline Grain sorghum & 1.01 & 1.00 & 0.26 & 1.26 & 1.28 & 0.42 \\
\hline Amaranth & 0.97 & 0.96 & 0.14 & 1.01 & 1.25 & 0.55 \\
\hline Soybean & 0.87 & 0.90 & 0.28 & 1.23 & 1.19 & 0.16 \\
\hline Clover & 0.91 & 1.03 & 0.22 & 1.32 & 1.76 & 0.24 \\
\hline Hairy vetch & 0.78 & 0.81 & 0.26 & 3.12 & 2.39 & 1.09 \\
\hline Pea & 0.83 & 0.77 & 0.16 & 1.02 & 1.51 & 1.23 \\
\hline
\end{tabular}

growing two or more species together with the yields of growing the same crops as a mono-crop $[31,36]$. A LER greater than 1.0 indicated intercropped systems were advantageous, whereas a LER less than 1.0 showed a yield disadvantage $[31,36]$. Drought greatly impacted LER values in 2012. Due to no intercrop production after wheat harvest (by midsummer), with the exception of grain sorghum and clover in $38 \mathrm{~cm}$ rows, all LER values were below 1.0 (Table 6). This was reasonable since the relay-intercrop system failed leaving only wheat yields as the marketable product. However, the double-crop system did provide some yield. Thus this pure yield would increase the LER value of the field by producing two yields in one growing season when compared with the mono-crop system.

Interestingly, there was successful alternative crop production in the relay-intercropping system in 2013 and LER values across all alternative crops, with the exception of pearl millet, were above 1.0 (Table 6). Hairy vetch had the greatest LER value across row spacing with 1.2 to 2.15 greater LER values compared with all intercrops. This corresponded with visual observations of large amounts of hairy vetch biomass production. In addition, $19 \mathrm{~cm}$ spacing LER was significantly greater than $38 \mathrm{~cm}$ row spacing. By producing positive LER values representing yield advantages of the intercropping system, using intercrops as forages or green manures, may potentially benefit farmers' production systems in years with low rainfall and temperatures (2013) but not in years with low rainfall and high temperatures (2012).

\section{Conclusion}

This research was conducted during extreme drought conditions in 2011-2012 and flash drought in 2012-2013. Winter wheat yields were not impacted as the majority of its lifecycle was completed during traditionally wetter periods of the year; however, alternative crop yields were decreased with the lowest establishment and survival in 2012. Spacing of wheat rows impacted wheat yields, as well as the type of cropping system for some alternative crops. In 2012, there were no alternative crop yields for the relay-intercrop or mono-crop system due to extreme drought conditions; however, wider row spacings or the double-crop system increased yield due to interference for resources with wheat in 2013. Land equivalent ratio values determining productivity of intercrop systems of 19 and $38 \mathrm{~cm}$ row spacing compared with sole-cropping systems showed that, with the exception of grain sorghum and $38 \mathrm{~cm}$ row spacing clover, there was no yield advantage for the intercropping system for any alternative crops in 2012. In 2013, LER values showed an advantage for all alternative crops with the exception of pearl millet in $19 \mathrm{~cm}$ spacing. This signified that farmers in Northeast Missouri could potentially boost their yield potential for a given field and perhaps produce additional forage or green manure yields in a year with a less severe drought.

\section{Conflict of Interests}

The authors declare that there is no conflict of interests regarding the publication of this paper.

\section{Acknowledgments}

The authors acknowledge the assistance of Dr. Kelly Nelson, the head agronomist at the University of Missouri's Greenley Memorial Research Center, for all of his support, knowledge, teaching, and inspiration. Thanks are to all the staff and employees at the Greenley Research Center, especially to Randall Smoot, Chris Dudenhoeffer, and Jeremy Holman, for all of their help, guidance, and patience.

\section{References}

[1] R. J. Crabtree, J. D. Prater, and P. Mbolda, "Long-term wheat, soybean, and grain sorghum double-cropping under rainfed conditions," Agronomy Journal, vol. 82, no. 4, pp. 683-686, 1990.

[2] E. E. Pullins, R. L. Myers, and H. C. Minor, Alternative Crops in Double-Crop Systems for Missouri, University Extension, University of Missouri, Columbia, Mo, USA, 1997.

[3] S. Kyei-Boahen and L. Zhang, "Early-maturing soybean in a wheat-soybean double-crop system: yield and net returns," Agronomy Journal, vol. 98, no. 2, pp. 295-301, 2006.

[4] O. P. Caviglia, V. O. Sadras, and F. H. Andrade, "Yield and quality of wheat and soybean in sole- and double-cropping," Agronomy Journal, vol. 103, no. 4, pp. 1081-1089, 2011.

[5] N. V. van Opstal, O. P. Caviglia, and R. J. M. Melchiori, "Water and solar radiation productivity of double-crops in a humid temperate area," Australian Journal of Crop Science, vol. 5, no. 13, pp. 1760-1766, 2011. 
[6] O. P. Caviglia, V. O. Sadras, and F. H. Andrade, "Intensification of agriculture in the south-eastern Pampas I. Capture and efficiency in the use of water and radiation in double-cropped wheat-soybean," Field Crops Research, vol. 87, no. 2-3, pp. 117129, 2004.

[7] A. S. Lithourgidis, C. A. Dordas, C. A. Damalas, and D. N. Vlachostergios, "Annual intercrops: an alternative pathway for sustainable agriculture," Australian Journal of Crop Science, vol. 5, no. 4, pp. 396-410, 2011.

[8] K. Fujita, K. G. Ofosu-Budu, and S. Ogata, "Biological nitrogen fixation in mixed legume-cereal cropping systems," Plant and Soil, vol. 141, no. 1-2, pp. 155-175, 1992.

[9] D. J. Midmore, "Agronomic modification of resource use and intercrop productivity," Field Crops Research, vol. 34, no. 3-4, pp. 357-380, 1993.

[10] J. R. T. Martens, J. W. Hoeppner, and M. H. Entz, "Legume cover crops with winter cereals in southern manitoba: establishment, productivity, and microclimate effects," Agronomy Journal, vol. 93, no. 5, pp. 1086-1096, 2001.

[11] H. Eskandari and A. Ghanbari, "Effect of different planting pattern of wheat (Triticum aestivum) and bean (Vicia faba) on grain yield, dry matter production and weed biomass," Notulae Scientia Biologicae, no. 2, pp. 111-115, 2010.

[12] L. Echarte, A. D. Maggiora, D. Cerrudo et al., "Yield response to plant density of maize and sunflower intercropped with soybean," Field Crops Research, vol. 121, no. 3, pp. 423-429, 2011.

[13] H. Eskandari, "Intercropping of wheat (Triticum aestivum) and bean (Vicia faba): effects of complementarity and competition of intercrop components in resource consumption on dry matter production and weed growth," African Journal of Biotechnology, vol. 10, no. 77, pp. 17755-17762, 2011.

[14] M. Hussain, Z. Mehmood, M. B. Khan, S. Farooq, D.-J. Lee, and M. Farooq, "Narrow row spacing ensures higher productivity of low tillering wheat cultivars," International Journal of Agriculture and Biology, vol. 14, no. 3, pp. 413-418, 2012.

[15] L. Coll, A. Cerrudo, R. Rizzalli, J. P. Monzon, and F. H. Andrade, "Capture and use of water and radiation in summer intercrops in the South-east Pampas of Argentina," Field Crops Research, vol. 134, pp. 105-113, 2012.

[16] X. B. Zhou, Y. H. Chen, and Z. Ouyang, "Effects of row spacing on soil water and water consumption of winter wheat under irrigated and rainfed conditions," Plant, Soil and Environment, vol. 57, no. 3, pp. 115-121, 2011.

[17] B. P. Pandey, K. B. Basnet, M. R. Bhatta, S. K. Sah, R. B. Thapa, and T. P. Kandel, "Effect of row spacing and direction of sowing on yield and yield attributing characters of wheat cultivated in Western Chitwan, Nepal," Agricultural Sciences, vol. 4, no. 7, pp. 309-316, 2013.

[18] M. Hozayn, T. A.-E. El-Shahawy, and F. A. Sharara, "Implication of crop row orientation and row spacing for controlling weeds and increasing yield in wheat," Australian Journal of Basic and Applied Sciences, vol. 6, no. 3, pp. 422-427, 2012.

[19] C. P. D. Borger, A. Hashem, and S. Pathan, "Manipulating crop row orientation to suppress weeds and increase crop yield," Weed Science, vol. 58, no. 2, pp. 174-178, 2010.

[20] B. C. Blaser, J. W. Singer, and L. R. Gibson, "Winter cereal, seeding rate, and intercrop seeding rate effect on red clover yield and quality," Agronomy Journal, vol. 99, no. 3, pp. 723-729, 2007.

[21] G. T. Champion, R. J. Froud-Williams, and J. M. Holland, "Interactions between wheat (Triticum aestivum L.) cultivar, row spacing and density and the effect on weed suppression and crop yield," Annals of Applied Biology, vol. 133, no. 3, pp. 443453, 1998.

[22] M. D. Thorsted, J. E. Olesen, and J. Weiner, "Width of clover strips and wheat rows influence grain yield in winter wheat/ white clover intercropping," Field Crops Research, vol. 95, no. 23, pp. 280-290, 2006.

[23] P. M. Porter and A. Khalilian, "Wheat response to row spacing in relay intercropping systems," Agronomy Journal, vol. 87, no. 5, pp. 999-1003, 1995.

[24] S. Drews, D. Neuhoff, and U. Köpke, "Weed suppression ability of three winter wheat varieties at different row spacing under organic farming conditions," Weed Research, vol. 49, no. 5, pp. 526-533, 2009.

[25] G. Tosti and M. Guiducci, "Durum wheat-faba bean temporary intercropping: effects on nitrogen supply and wheat quality," European Journal of Agronomy, vol. 33, no. 3, pp. 157-165, 2010.

[26] J. Stute and K. Shelley, Frost Seeding Red Clover in Winter Wheat, University of Wisconsin Extension: Nutrient and Pest Management Program, Madison, Wis, USA, 2008.

[27] L. E. Gentry, S. S. Snapp, R. F. Price, and L. F. Gentry, "Apparent red clover nitrogen credit to corn: evaluating cover crop introduction," Agronomy Journal, vol. 105, no. 6, pp. 16581664, 2013.

[28] A. C. M. Gaudin, K. Janovicek, R. C. Martin, and W. Deen, "Approaches to optimizing nitrogen fertilization in a winter wheat-red clover (Trifolium pratense L.) relay cropping system," Field Crops Research, vol. 155, pp. 192-201, 2014.

[29] L. O. Brandsæter, T. Smeby, A. M. Tronsmo, and J. Netland, "Winter annual legumes for use as cover crops in row crops in northern regions: II. Frost resistance study," Crop Science, vol. 40, no. 1, pp. 175-181, 2000.

[30] K. Nelson, C. Bliefert, R. Smoot, J. Bryant, and D. Harder, "Double-crop buckwheat, sunflower, and soybean comparison," MO Ag Experiment Station-Greenley Memorial Research Center, 2000.

[31] E. Malézieux, Y. Crozat, C. Dupraz et al., "Mixing plant species in cropping systems: concepts, tools and models. A review," Agronomy for Sustainable Development, vol. 29, no. 1, pp. 43-62, 2009.

[32] SAS Institute, SAS User's Guide, SAS Institute, Cary, NC, USA, 2010.

[33] USDA National Agriculture Statistics Service, Wheat facts, National Agricultural Statistic Service, Washington, DC, USA, 2010, http://www.nass.usda.gov/Statistics_by_State/Missouri/ Publications/Brochures/Wheat_Facts.pdf.

[34] C. F. Ngalla and D. J. Eckert, "Wheat-red clover interseeding as a nitrogen source for corn," in The Role of Legumes on Conservation Tillage Systems, J. F. Power, Ed., Proceedings of the Soil Conservation Society of America, pp. 47-48, Soil Conservation Society of America, Athens, Ga, USA, 1987.

[35] L. O. Brandsæter and J. Netland, "Winter annual legumes for use as cover crops in row crops in northern regions. I. Field experiments," Crop Science, vol. 39, no. 5, pp. 1369-1379, 1999.

[36] A. S. Lithourgidis, D. N. Vlachostergios, C. A. Dordas, and C. A. Damalas, "Dry matter yield, nitrogen content, and competition in pea-cereal intercropping systems," European Journal of Agronomy, vol. 34, no. 4, pp. 287-294, 2011. 


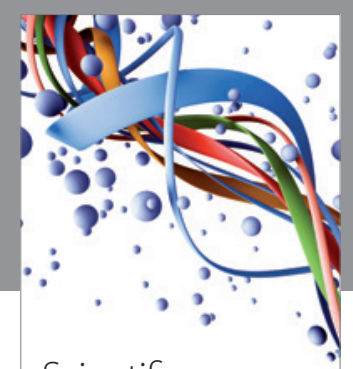

Scientifica
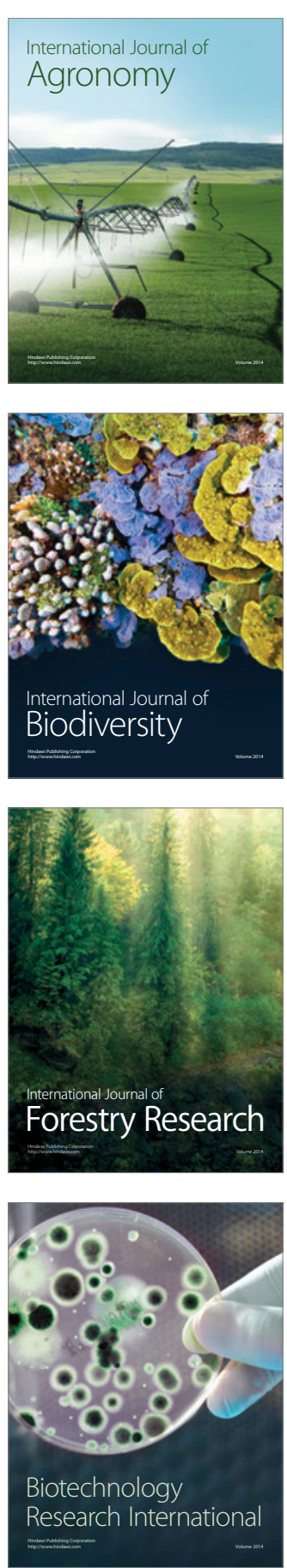
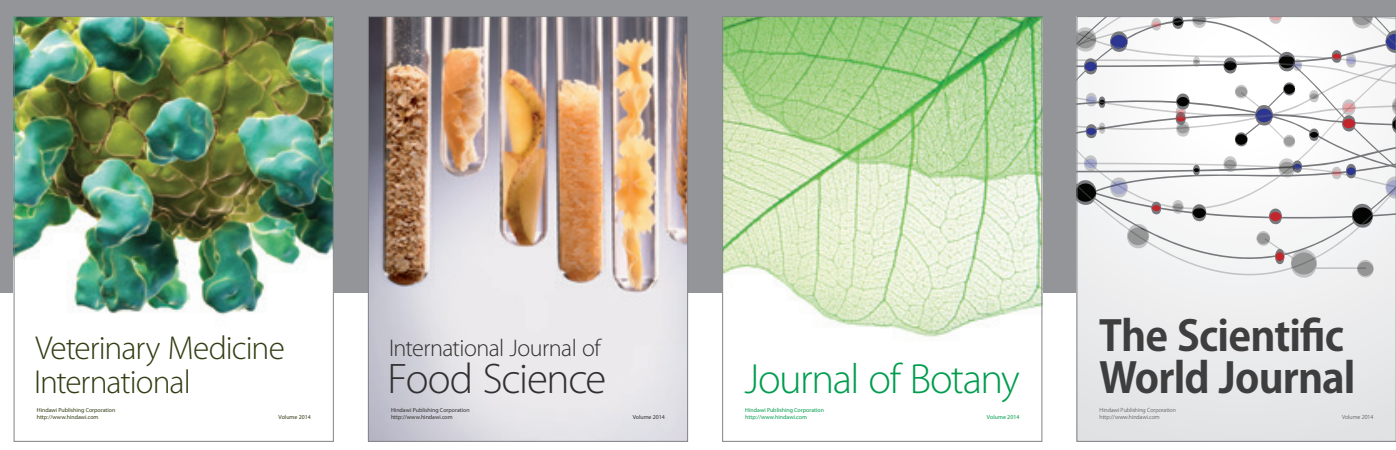

The Scientific World Journal
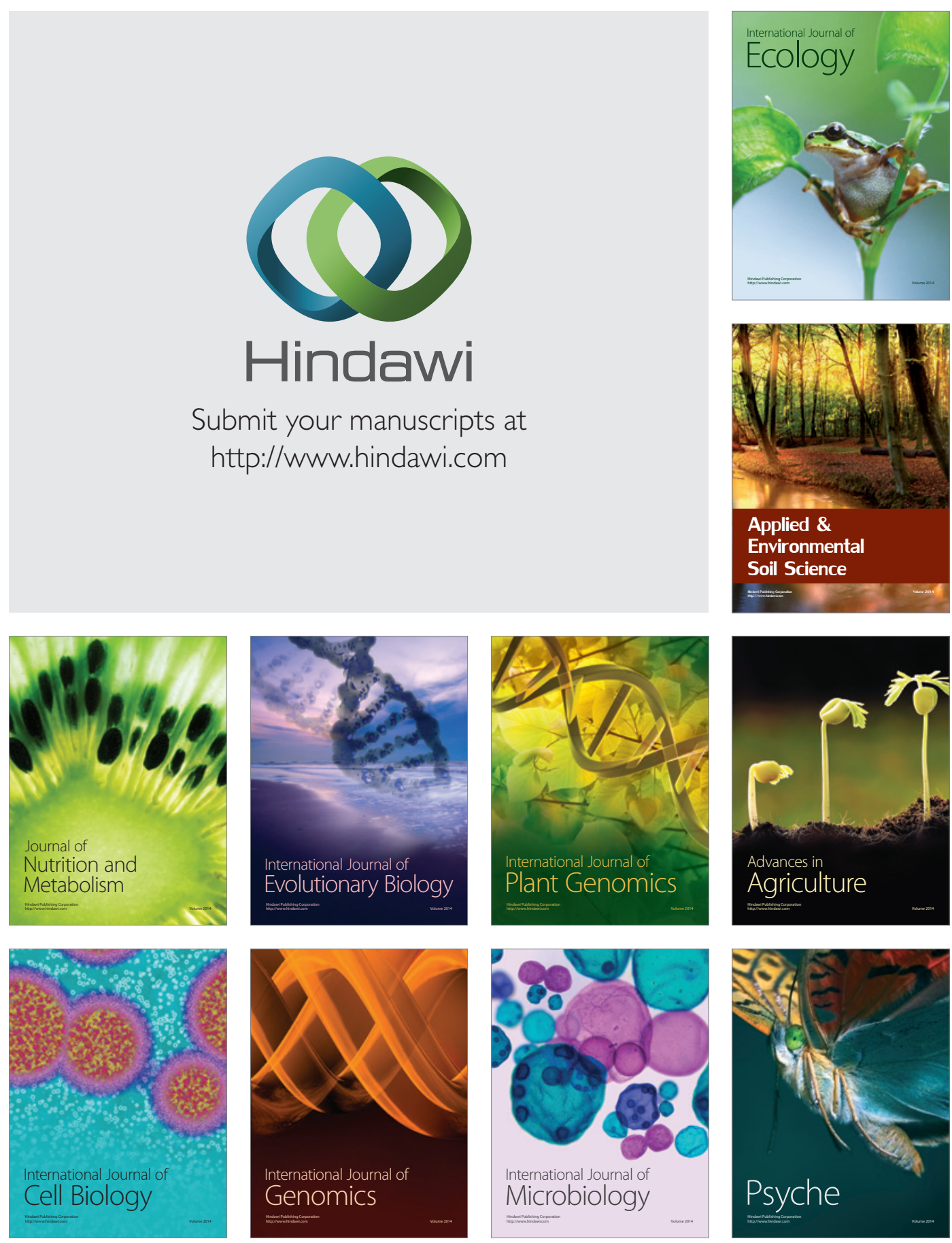